\title{
Pembangunan Sistem Pengelolaan Hosting dan Collocation pada Kementerian Kesehatan RI Berbasis Website Menggunakan Metode Waterfall
}

\author{
Ady Purna Kurniawan ${ }^{1}$, Mutia Qona'a ${ }^{2}$, Genta Mahdyan Rizqy ${ }^{3}$ \\ Fakultas Ilmu Terapan, Universitas Telkom \\ e-mail: ${ }^{1}$ adypurnakurniawan@ @elkomuniversity.ac.id, ${ }^{2}$ gentamahdyan@gmail.com, \\ ${ }^{3}$ mutia@tass.telkomuniversity.ac.id
}

Diterima: 20 Agustus 2020; Direvisi: 09 September 2020; Disetujui: 29 September 2020

\begin{abstract}
Abstrak
Pengelolaan hosting dan collocation termasuk kegiatan yang diajukan oleh staff satuan kerja di lingkungan Kementerian Kesehatan Republik Indonesia untuk mempermudah dalam pendaftaran kegiatan hosting, collocation, update data hosting upgrade space hosting dan juga laporan penyerahan hosting. Namun proses yang berlangsung saat ini masih menggunakan aplikasi Microsoft Word dan berbasis kertas. Pembangunan sistem ini bertujuan untuk memudahkan kepala bagian dalam proses approval pengajuan kegiatan yang telah diajukan oleh staff satuan kerja. Sistem ini dibangun berbasis website menggunakan framework CodeIgniter, serta dikembangkan menggunakan metode Waterfall. Pengujian sistem menggunakan metode WebQual 4.0 dimana seluruh responden menyatakan bahwa system mudah digunakan, serta memiliki informasi dan interaksi yang berkualitas. Hasil dari pembangunan sistem ini dapat menggantikan proses pengaujuan kegiatan yang semula berbasis kertas menjadi komputeriasasi untuk digunakan dan diterapkan oleh bagian Pusat Data dan Informasi, Kementerian Kesehatan Republik Indonesia.
\end{abstract}

Kata kunci: Sistem Informasi, Hosting, Collocation, Website, Waterfall

\begin{abstract}
Management of hosting and collocation are activities proposed by unit staff within the Ministry of Health of the RI to facilitate the registration for hosting, collocation, updating hosting data, upgrading hosting space and hosting submission reports. However, the process that is currently used still using Microsoft Word and paper-based applications. The purpose of this system development is to facilitate the head of the department in the approval process for submitting activities that have been submitted by staff. This system was built based on a website using the CodeIgniter framework, and was developed using the Waterfall method. The system testing used the WebQual 4.0 method in which all respondents stated that the system is easy to use, and has quality information and interactions. The results of the system development can replace the process of filing activities that were originally based on paper into computerization, which are used and implemented by the Center for Data and Information, Ministry of Health of the RI.
\end{abstract}

Keywords: Information System, Hosting, Collocation, Website, Waterfall 


\section{PENDAHULUAN}

Peran dan dukungan teknologi informasi sangat dibutuhkan untuk menunjang kebutuhan dan pengelolaan data dalam sebuah institusi. Data yang berkualitas dapat membantu dan meningkatkan efesiensi kerja para staff yang menjalankan bisnis pada institusi tersebut. Selain itu, tujuan dari institusi juga dapat tercapai berkat adanya teknologi yang sesuai dengan kebutuhan penggunanya[1]. Kementerian adalah institusi milik negara yang sangat krusial dan harus mendapatkan sarana penunjang yang berkualitas tersebut. Kementerian Kesehatan adalah kementerian dalam Pemerintah Indonesia yang membidangi urusan kesehatan dan juga merupakan pusat kesehatan yang berada dibawah dan bertanggung jawab kepada Presiden. Pusat Data dan Informasi adalah unit yang melaksanakan penyusunan kebijakan teknis, pelaksanaan, pemantauan, evaluasi dan pelaporan di bidang pengelolaan data dan informasi sesuai dengan ketentuan peraturan perundang-undangan. Sesuai dengan tugasnya maka unit ini terdiri dari Bagian Tata Usaha, Bidang Pengembangan Sistem Informasi, Bidang Pengelolaan Teknologi Informasi, dan Bidang Pengelolaan Data dan Informasi[2].

Di setiap unit atau satuan kerja yang berada di Kementrian Kesehatan Republik Indonesia hampir semua memiliki sistem informasi, hal ini memungkinkan setiap saat melakukan update data atau informasi melalui media internet dengan cara melakukan pengajuan hosting dan collocation yang mempunyai peran untuk menyediakan layanan untuk penempatan server di Pusat Data Kementerian Kesehatan Republik Indonesia. Data dan informasi akan digunakan untuk penyiapan penyusunan kebijakan di bidang pengumpulan, pengolahan, analisis data kesehatan, penyajian, diseminasi, dan pelayanan informasi kesehatan. Unit Pusat Data dan Informasi memiliki bidang yang membawahi tentang informasi atau data yang telah dikumpulkan dan akan di-update melalui media web dengan hosting tersebut.

Satuan kerja memiliki masalah pada pengajuan kegiatan serta bagian pusat data dan informasi yang mengelola dokumen pengajuan kegiatan dan pengajuan space hosting yang masih dilakukan dengan cara komunikasi yang berdampak tidak ada nya bukti fisik laporan upgrade space pada hosting. Pengajuan kegiatan yang membutuhkan waktu lama dan masih secara manual serta dokumen pengajuan kegiatan yang masih dikelola menggunakan kertas. Pengajuan kegiatan tersebut masih memakan waktu karena setiap bidang harus mencetak form sebelum mereka mengisi form tersebut. Penyimpanan dokumen yang masih menggunakan lembaran kertas yang ditumpuk berdampak pada pengelolaan dokumen sehingga saat data pengajuan hosting yang dibutuhkan bagian pusat data dan informasi akan sulit untuk menemukan dan mengelola data atau dokumen tersebut.

Dari permasalahan tersebut, pusat data dan informasi Kemenkes RI membutuhkan suatu sistem yang mampu mengelola data dan informasi. Beberapa fitur utama yang dibutuhkan adalah pendaftaran pengajuan kegiatan hosting, pengajuan collocation, laporan pengajuan kegiatan dan pengelolaan dokumen pengajuan kegiatan. Di samping itu, dengan adanya aplikasi ini dapat mempermudah satuan kerja dalam mengelola arsip pengajuan kegiatan yang tersimpan ke dalam database yang dikelola secara langsung oleh bagian pusat data dan informasi.

\section{METODE PENGEMBANGAN}

Dalam pembangunan sistem informasi ini digunakan metode turunan dari Software Development Life Cycle (SDLC) yaitu metode Waterfall karena hasil akhir pengembangan sistem masih dapat dikembangkan kembali pada tahap-tahap tertentu[3]. Gambaran tahapan metode Waterfall dapat dilihat pada gambar 1. 


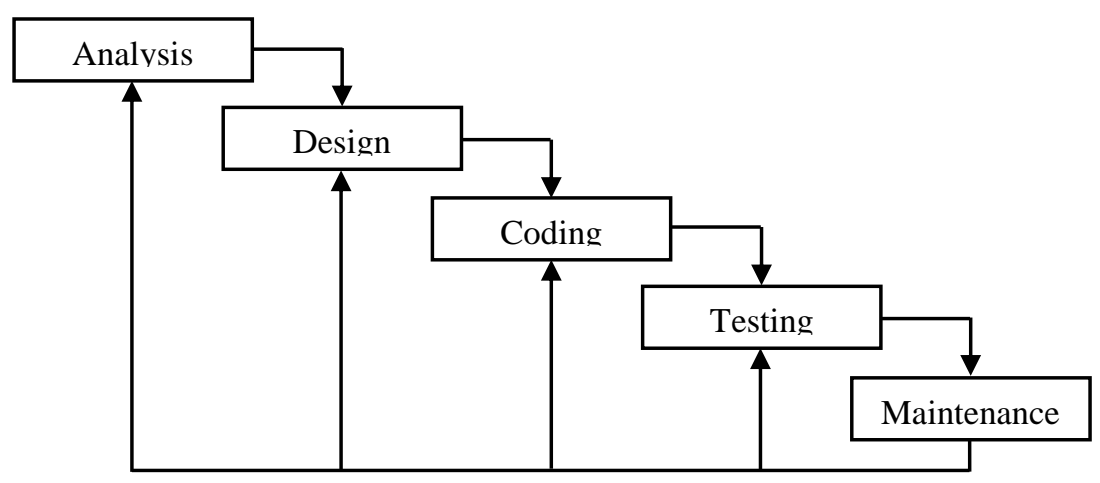

Gambar 1. Metode Waterfall [4]

Penjelasan tiap tahapan pada pengembangan sistem menggunkan metode Waterfall tersebut adalah sebagai berikut :

1) Analisis Kebutuhan (Analysis)

Pada tahap pertama ini yang harus dilakukan adalah bagaimana kebutuhan sistem nantinya. Maka dengan itu dilakukan wawancara langsung kepada pihak Kementerian Kesehatan Republik Indonesia bagian pusat data dan informasi untuk mengumpulkan dokumen-dokumen yang diperlukan.

\section{2) Perancangan (Design)}

Pada tahap kedua yang harus dilakukan adalah merancang tampilan dan data-data yang harus sesuai dengan kebutuhan user. Perancangan ini berdasarkan proses bisnis dengan menggunakan tools seperti Entity Relationship Diagram (ERD) dan Data Flow Diagram (DFD) yang sesuai dengan apa yang dibutuhkan pada Kementrerian Kesehatan bidang Pusat Data dan Informasi.

3) Pembangunan (Building/coding)

Tahap ketiga adalah coding, tahap ini dilakukan jika kebutuhan dan desain telah dibuat dan disetujui oleh bagian Pusat Data dan Informasi. Dalam penerapan tahap ini menggunakan framework CodeIgniter dengan basis bahasa pemrograman web.

4) Pengujian (Testing)

Tahap pengujian pada aplikasi pengajuan kegiatan di Kementerian Kesehatan terutama bidang Pusat Data dan Informasi. Testing akan dibagi menjadi dua tahap yaitu blackbox yang akan dilakukan oleh programmer dan UAT (User Acceptance Test) yang dilakukan oleh pengguna akhir sistem menggunakan metode WebQual 4.0[3][5].

5) Perawatan (Maintenance)

Tahap perawatan perangkat lunak dijalankan oleh Pusat Data dan Informasi serta dilakukan pemeliharaan. Pemeliharaan sistem termasuk memperbaiki kesalahan yang tidak ditemukan sebelumnya saat dilakukan pengujian[6].

\section{HASIL DAN PEMBAHASAN}

\subsection{Hasil Pembangunan Sistem}

Pembangunan Sistem Informasi ini melalui beberapa tahap dalam metode Waterfall sesuai pada Gambar 1, dimana kebutuhan utama proses berasal dari Pusat Data dan Informasi Kementerian RI. Dari kebutuhan-kebutuhan tersebut selanjutnya dilakukan proses desain sistem baik dari sisi fungsional maupun non-fungsional, dimana hasil desain tersebut menjadi dasar pembangunan sistem. Pada tahap pembangunan sistem ini dilakukan proses coding yang bertujuan menyediakan fungsi dalam memenuhi kebutuhan pengguna, fungsi-fungsi tersebut antara lain :

1) Dashboard satuan kerja 
Gambar 2 merupakan implementasi antarmuka dashboard data pengajuan yang sudah dilakukan. Pada halaman dashboard ini juga terdapat tracking pengajuan yang telah diajukan sebelumnya.

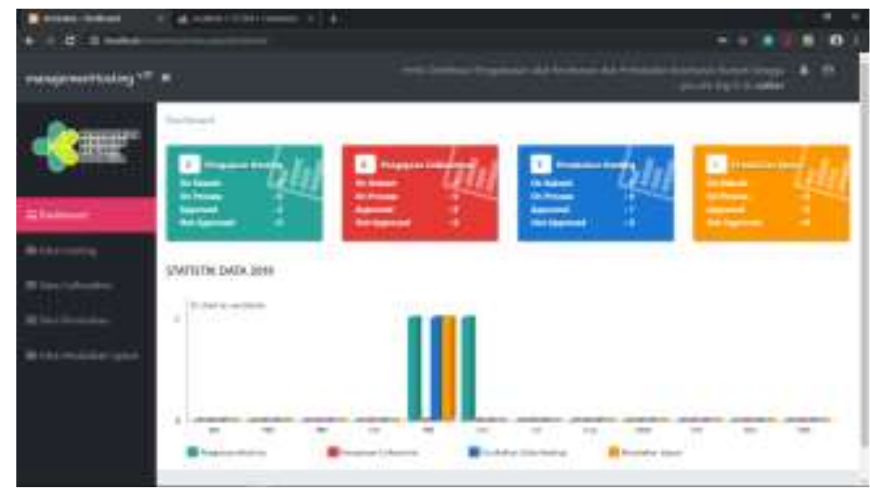

Gambar 2. Tampilan Dashboard Satuan Kerja

2) Tampilan data pengajuan satuan kerja

Gambar 3 merupakan implementasi antarmuka tampilan data pengajuan yang telah diajukan oleh satuan kerja. Terdapat data pengajuan hosting, pengajuan collocation, pengajuan perubahan hosting dan pengajuan space hosting.

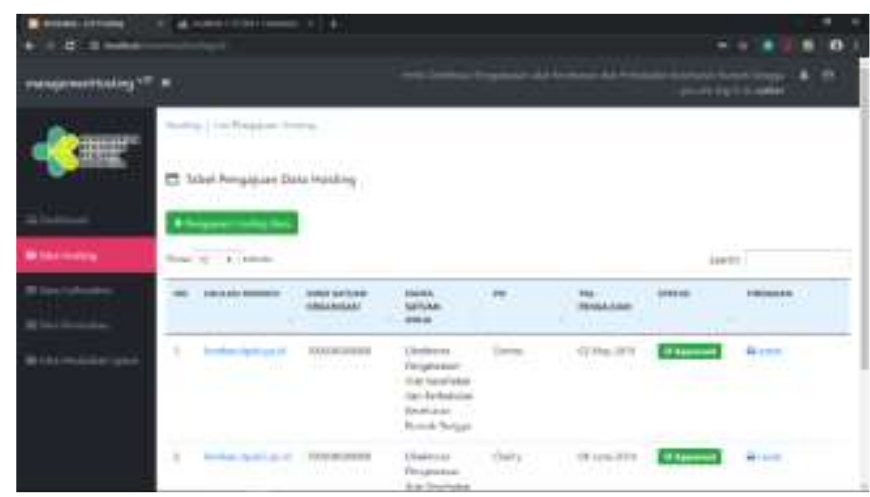

Gambar 3. Tampilan Data Pengajuan Satuan Kerja

3) Form pengajuan hosting

Gambar 4 merupakan implementasi antarmuka form pengajuan hosting yang harus diisi oleh satuan kerja. Semua data harus terisi untuk dapat menginputkan form pengajuan.

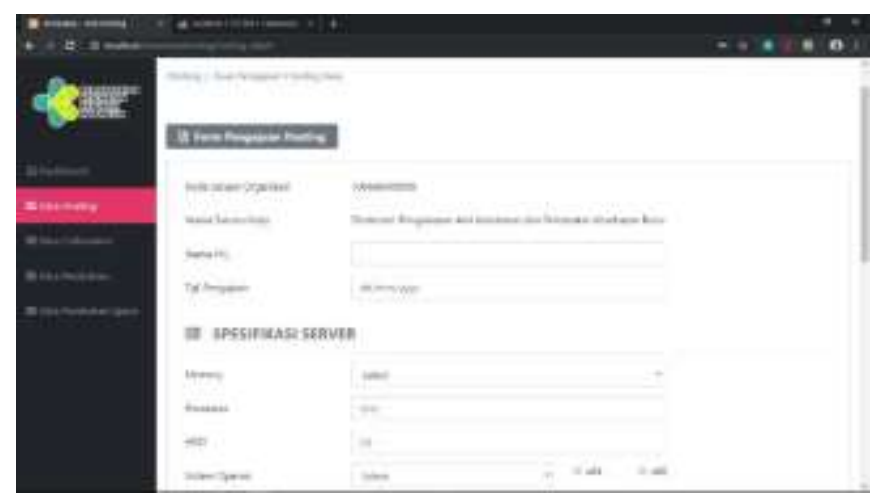

Gambar 4. Tampilan Form Pengajuan Hosting 
4) Form pengajuan collocation

Gambar 5 merupakan implementasi antarmuka form pengajuan collocation yang harus diisi oleh satuan kerja, ada sedikit perbedaan form dengan pengajuan hosting. Semua data harus terisi untuk dapat menginputkan form pengajuan.

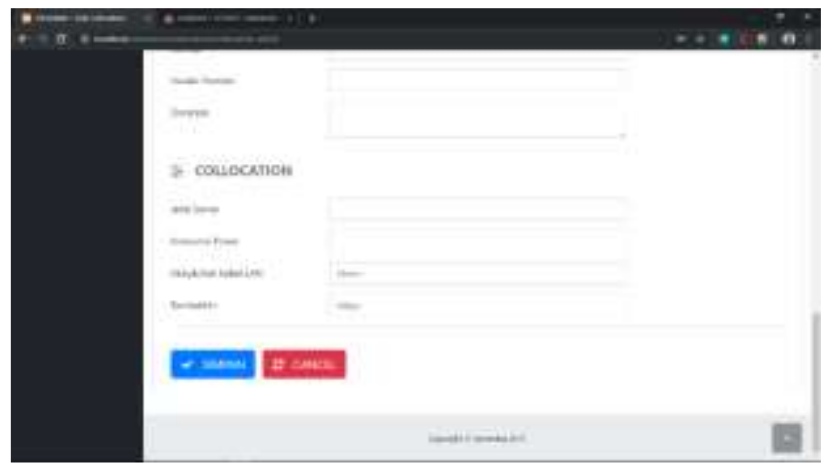

Gambar 5. Tampilan Form Pengajuan Hosting

5) Form pengajuan perubahan hosting

Gambar 6 merupakan implementasi antarmuka form pengajuan perubahan hosting yang harus diisi oleh aktor satuan kerja. Staff satuan kerja hanya mengisi sebagian data pada form ini, sedangkan data lainnya diisi oleh staff satuan kerja setelah form disubmit.

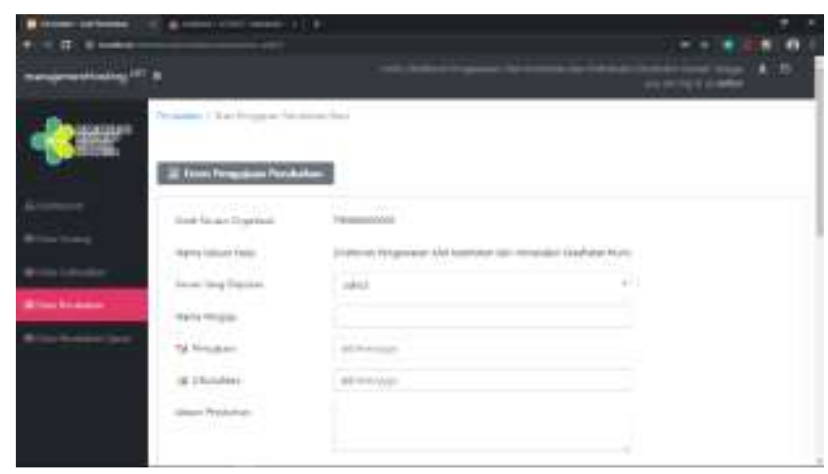

Gambar 6. Tampilan Form Pengajuan Perubahan Hosting

6) Form pengajuan space hosting

Gambar 7 merupakan implementasi antarmuka form pengajuan space hosting yang harus diisi oleh satuan kerja. Hanya sebagian form yang diisi sedangkan lainnya diisi oleh staff satuan kerja.

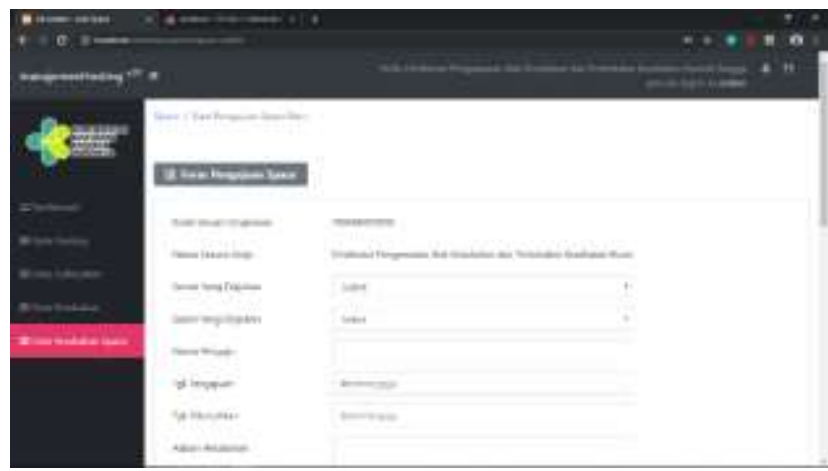

Gambar 7. Tampilan Form Pengajuan Space Hosting 
7) Tampilan form update pengajuan hosting

Gambar 8 merupakan implementasi antarmuka tampilan form update pengajuan hosting yang dilakukan oleh aktor staff pusat data dan informasi untuk mengelola pengajuan hosting.

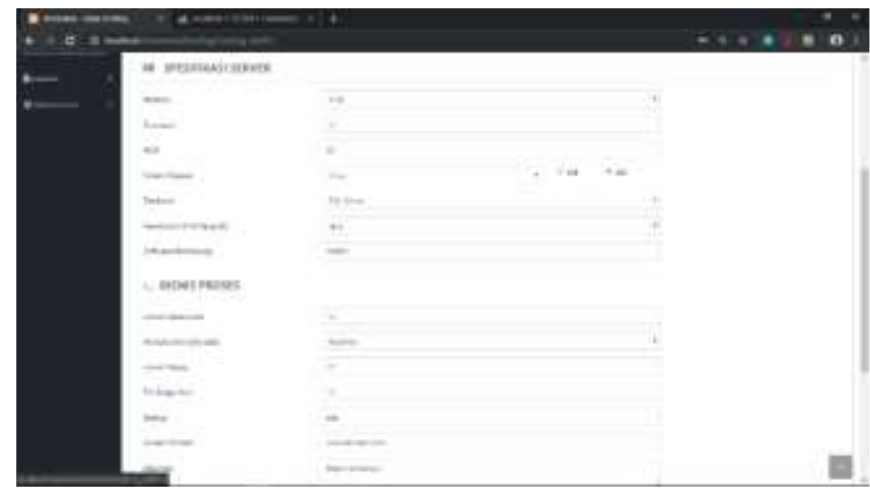

Gambar 8. Tampilan Form Update Hosting

8) Tampilan approval dan catatan kepala bidang

Gambar 9 merupakan implementasi antarmuka approval dan catatan kepala bidang untuk setiap pengajuan hosting, pengajuan collocation, pengajuan perubahan hosting, pengajuan space hosting. Di tampilan ini proses approval oleh kepala akan dilakukan.

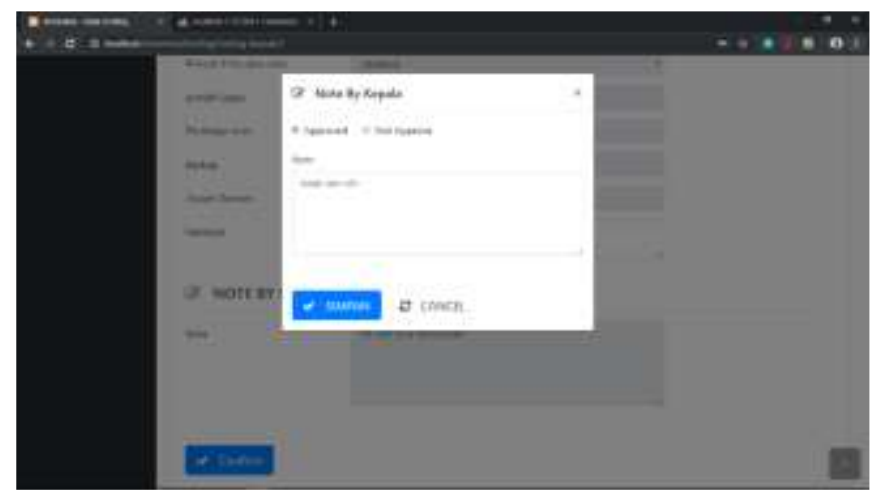

Gambar 9. Tampilan Approval dan Catatan

\subsection{Pengujian Sistem}

Setelah seluruh fungsi dibuat dalam sistem informasi, selanjutnya dilakukan pengujian baik dari sisi pengembang maupun pengguna. Pengujian dari sisi pengembang dilakukan secara langsung setelah seluruh fungsi selesai menggunakan metode BlackBox, dimana pada pengujian ini hanya melihat fungsional sistem secara umum. Selanjutnya sistem informasi diujikan kepada seluruh aktor yang memiliki hak akses langsung di Kementerian Kesehatan RI. Gambar 10 adalah hasil pengujian UAT (User Acceptance Test) yang telah dilaksanakan. Penilaian ini dilakukan secara langsung dengan mengoperasikan sistem dan menggunakan kuisioner dari instrument metode WebQual 4.0[1] yang diberikan kepada 3 (tiga) responden selaku pengguna akhir sistem yaitu staff satuan kerja, staff pusat data dan informasi dan juga kepala bidang.

Tabel 1 memberikan detail pertanyaan sesuai metode WebQual 4.0 mengenai pengukuran kualitas website dengan pilihan jawaban berdasarkan skala Likert yang meliputi STS (Sangat Tidak Setuju), TS (tidak Setuju), S (Setuju), dan SS (Sangat Setuju). 
Tabel 1. Hasil UAT Menggunakan WebQual 4.0

\begin{tabular}{llcccc}
\hline No & Pertanyaan/Pernyataan & \multicolumn{5}{c}{ Jumlah Jawaban } \\
\hline $\mathbf{1}$ & Usability & $\boldsymbol{S T S}$ & $\boldsymbol{T S}$ & $\boldsymbol{S}$ & $\boldsymbol{S S}$ \\
\hline 1.1 & Mudah dioperasikan & 0 & 0 & 1 & 2 \\
1.2 & Interaksi jelas dimengerti & 0 & 0 & 1 & 2 \\
1.3 & Navigasi yang mudah & 0 & 0 & 2 & 1 \\
1.4 & Mudah diakses & 0 & 0 & 1 & 2 \\
\hline 1.5 & Tata letak informasi yang tepat & 0 & 0 & 2 & 1 \\
1.6 & Informasi mudah ditemukan & 0 & 0 & 0 & 3 \\
1.7 & Komponen sesuai kebutuhan & 0 & 0 & 0 & 3 \\
1.8 & Informasi memenuhi kebutuhan & 0 & 0 & 0 & 3 \\
1.9 & Desain yang sesuai & 0 & 0 & 1 & 2 \\
\hline $\mathbf{2}$ & Information Quality & & & & \\
\hline 2.1 & Informasi yang jelas & 0 & 0 & 0 & 3 \\
2.2 & Informasi yang dipercaya & 0 & 0 & 0 & 3 \\
2.3 & Informasi selalu up-to-date & 0 & 0 & 2 & 1 \\
2.4 & Informasi yang relevan & 0 & 0 & 2 & 1 \\
2.5 & Teks mudah dipahami/dibaca & 0 & 0 & 1 & 2 \\
2.6 & Gambar dapat dilihat jelas & 0 & 0 & 0 & 3 \\
2.7 & Informasi sangat detail & 0 & 0 & 0 & 3 \\
2.8 & Informasi sesuai format & 0 & 0 & 0 & 3 \\
\hline $\mathbf{3}$ & Interaction Quality & & & & \\
\hline 3.1 & Tidak mengalami error & 0 & 0 & 0 & 3 \\
3.2 & File aman dari virus & 0 & 0 & 0 & 3 \\
3.3 & File/data terjaga kerahasiannya & 0 & 0 & 0 & 3 \\
3.4 & Tampilan web menarik minat & 0 & 0 & 1 & 2 \\
3.5 & Fasilitas komunikasi antar user & 0 & 0 & 2 & 1 \\
3.6 & Fasilitas feedback & 0 & 0 & 1 & 3 \\
3.7 & Tingkat kepercayaan yang tinggi & 0 & 0 & 2 & 1 \\
3.8 & Pembaharuan layanan & & & & 1 \\
\hline & & 0 & 0 & 0 & 0
\end{tabular}

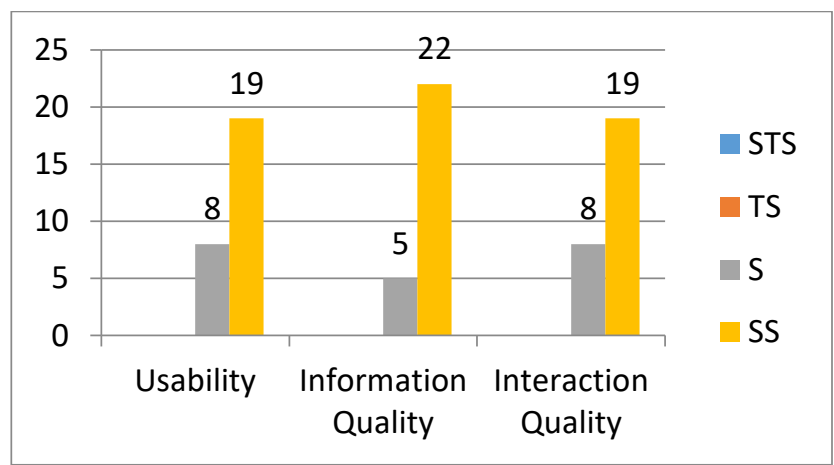

Gambar 10. Rekapitulasi Hasil UAT Menggunakan WebQual 4.0

Gambar 10 memberikan penjelasan bahwa dapat disimpulkan mayoritas pengguna (user) sangat setuju dengan pernyataan di setiap pertanyaan pada kuesioner, sedangkan sisanya menyatakan setuju dengan pernyataan pada kuesioner. Tidak ada pengguna yang menyatakan tidak setuju dan sangat tidak setuju pada satu pun pernyataan tersebut. Hal ini menandakan bahkan setiap elemen pada sistem informasi sudah sesuai dengan kebutuhan pengguna. Kesimpulan setelah proses penggujian akhir ini adalah :

1. Interaksi aplikasi dan pengguna pada aplikasi sudah diterima dengan baik dan sesuai kebutuhan pengguna.

2. Pengembang dan staff telah mengecek setiap fungsionalitas yang berjalan dengan memasukkan data. 


\section{KESIMPULAN}

Adapun kesimpulan yang dapat diambil dari pengembangan sistem pengajuan pendaftaran kegiatan di pusat data dan Informasi Kementerian Kesehatan Republik Indonesia yaitu sistem pengajuan pendaftaran kegiatan di pusat data dan informasi memiliki fungsi utama diantaranya pendaftaran pengajuan hosting, pengajuan collocation, pengajuan perubahan hosting dan juga pengajuan space hosting. Seluruh pengguna (100\%) sistem di Pusat Data dan Informasi menyatakan setuju dengan pernyataan dalam metode WebQual 4.0 dalam tahap pengujian yang menilai 3 elemen yaitu usability, information quality, dan interaction quality.

\section{SARAN}

Sistem informasi yang telah dibangun sudah sesuai dengan kebutuhan pengguna di Pusat Data dan Informasi Kementrian Kesehatan RI, namun ada beberapa saran terkait pengembangan sistem selanjutnya diantaranya sistem dapat dikembangkan dalam versi mobile, sehingga actor dalam sistem dapat langsung mengakses data tanpa harus menuju browser terlebih dahulu. Kemudian adanya dukungan fitur SMS Gateway agar aktor dapat langsung menerima pemberitahuan saat ada pengajuan kegiatan baru atau perubahan data, sehingga aktor dapat langsung bertindak dimana dapat mempercepat proses.

\section{DAFTAR PUSTAKA}

[1] Kurniawan, Ady Purna. "Pengukuran Kualitas Website Universitas Telkom Menggunakan Metode WebQual 4.0". Prosiding Centive 2018, IT Telkom Purwokerto, 2018.

[2] Pusat Data dan Informasi. Kedudukan, Tugas dan Fungsi. 2014.

[Online] Available at http://www.pusdatin.kemkes.go.id/article/view/13010100003/tugasdan-fungsi-pusdatin.html. [Accessed 5 November 2018]

[3] Kurniawan, Ady Purna. "Pembangunan Sistem Informasi Pengolahan Data Produksi Pada UMKM Konfeksi Berbasis Website". Jurnal of Technology and Information System, Vol. 1 No.3 (2018), ISSN : 2614 - 3070, E-ISSN : 2614 - 3089, Hal. 80-84.

[4] R. S. Pressman, "Rekayasa Perangkat Lunak," in Buku Satu Pendekatan Praktisi (Edisi 7), Yogyakarta, Andi, 2012.

[5] E. W. Yunarso, Students Work Book Jaminan Mutu Sistem Informasi, Yogyakarta: deepublish, 2013.

[6] Nabila, Ishma, Agus Pratondo, and Siska Komala Sari. "Aplikasi Pengarsipan Surat Masuk Dan Surat Keluar Berbasis Web Studi Kasus Badan Kesatuan Bangsa Dan Politik Provinsi Jawa Barat." eProceedings of Applied Science 5, no. 3 (2019). 